\title{
Suggestions for Resolving the Social Conflict in Affordable Housing
}

\author{
Tae Soon Park ${ }^{1}$ and Mihong Lee ${ }^{2}$
}

(Received June 30, 2014 / Revised July 25, 2014 / Accepted July 28, 2014)

\begin{abstract}
The purpose of this study is to employ a method called 'conflict impact assessment' to analyze the progress, background, cause and relevant issues of conflicts related with affordable housing for youth (Happiness Housing Project), a project that has been implemented since last May 2013, thereby identifying the relevant problems and draw out objectives for improvement. The researchers expect that this study will contribute to solving the current issues regarding Happiness Housing, and contribute to improving the quality of the government's policies. For the above purpose, literatures on Happiness Housing produced from August to November 2013 were reviewed, in-depth telephone or face-to-face interviews were conducted with personnel associated with project implementation in the Ministry of Land, Infrastructure and Transportation and LH, etc., and major interested parties including Yangcheon-gu residents. Key issues identified regarding Happiness Housing construction include: the way that the project was implemented, living quality of residents, impact on educational environment, inconsistence with existing plans, relatively high construction cost, insolvency of public corporations, land use fee issue with Korail, need of preliminary feasibility survey, securing sufficient amount for supply and issue of additional designation, likelihood of finishing construction in time and issues related with actual source of demand, etc. Through analysis of conflict development and positions of interested parties, the main causes of the conflicts were identified as follows: lack of deliberation on pledges during election, lack of viability review on pledges, lack of conflict management plans, one-way implementation without consent of interested parties, project plans established with no regard to local circumstances, frequent project revision, underwehlming level of conflict management. In order to address issues above, the following measures need to be taken: selecting election pledges based on actual effectiveness, thorough assessment on pledges by relevant departments, gradual implementation based on consideration of the actual circumstances, participation of key interested parties, consistent policy and adopting conflict management techniques that reflect the reality.
\end{abstract}

Key words: Conflict Management, Conflict Impact Assessment, Public Conflict, Affordable Housing, Happiness Housing Project

\section{Introduction}

The "Happiness Housing Project" involves 'supplying houses of various types such as apartment housing, multi-household housing and multi-family housing to urban areas with population of 500 thousand or more where demand for rental housing is high and public transportation can be easily accessed.' (Ministry of Land, Infrastructure and Transport, 2014). When the Project was first adopted in 2013, however, the concept of the Project was more narrowly defined as 'constructing combined complexes for residential, commercial and other purposes on sites prepared on railroad sites and retarding basins, etc., and supplying houses preferentially to residentially disadvantaged classes including university students and newlyweds.'

Affordable housing greatly helps the socially vulnerable classes secure houses, as the houses are supplied at places with high accessibility to public transportation at 50 $80 \%$ of the market rent of the surrounding area. In addition, the project includes establishing commercial facilities and other facilities for the residents' convenience, thereby promoting revitalization of the local economies and even incorporating the concept of urban regeneration. Despite these good intentions, announcement of 7 pilot districts for the Happiness Housing Project by the Ministry of Land, Infrastructure and Transport (in May 2013) was met with serious opposition in various areas including Yangcheon-gu, with conflicts further escalating in some districts. In response, the Ministry set out to take various actions to resolve the conflicts, for example announcing the Follow-up Action Plan for Real Estate Policies in December 2013 which included plans to revise and supplement the targets, scope and procedures of the Affordable Housing

1) Director, Social Conflict Research Institute, Korea (Main author: parkts2923@socon.re.kr)

2) Research fellow, Land and Housing Institute, Korea Land \& Housing Corporation, Korea (Corresponding author: mihong@lh.or.kr) 
Project and amend the relevant laws. As a result of these actions, the level of conflicts has now subsided to some extent.

The purpose of this study is to employ a method called 'conflict impact assessment' to analyze the progress, background, cause and relevant issues of conflicts, thereby identifying the relevant problems and draw out objectives for improvement. For the above purpose, literatures on Happiness Housing Project were reviewed, and in-depth telephone or face-to-face interviews were conducted with personnel associated with project implementation in the Ministry of Land, Infrastructure and Transport and LH, etc., and major interested parties including Yangcheon-gu residents, from August to November 2013. Through this study, the authors hope to contribute to improving the quality of the government's policies, by resolving current issues with Happiness Housing Project presently under implementation, and drawing out improvement tasks for establishment and implementation of similar policies in the future.

\section{Literature Review}

The intial concept of Happiness Housing Project was building housing complexes on railroad sites. The concept, however, has now changed into building combined residential towns in conjunction with urban regeneration. Based on this changed concept, this section will review previous researches in the following topics: researches on conflicts generated from rental housing or urban regeneration projects, and institutional researches for conflict prevention (conflict impact assessment, etc.).

\subsection{Researches on Conflicts Generated from Rental Housing or Urban Regeneration Projects}

$\mathrm{Ha}$ and $\mathrm{Kim}(2007)$ analyzed conflict cases from LH civil complaints records and conducted interviews with government and LH employees in order to analyze types of conflicts between public sectors during the National Rental Housing Construction Project and propose methods for conflict management. From the analysis, the researchers suggested fundamental causes of such conflicts as follows: forced implementation of the National Rental Housing Construction Project, difficulties in consultation between public sectors when establishing the related plans, due to tight project schedule, and non-realistic construction cost. To deal with these issues, the researchers proposed conflict management based on the 'governance' concept. 1) Departure from forced implementation, policy review and regular feasibility review with participation from the government, local governments and public corporations, establishment of methods to promote participation from local governments, plans for active publicization, and upward planning. 2) Management methods for conflicts caused by unrealistic schedule were: parallel implementation of both arbitration through negotiation between the participating parties and arbitration through the arbitration committee, establishment of mutual trust by expanding opportunities for each party to participate, flexible application to each project district and forming a separate consultation body. 3) Conflict management methods related with unrealistic construction cost included: problem-solving through participation of relevant parties aimed at overcoming resistance against National Rental Housing Construction Project and supply of more diverse types of housing.

Park and Song(2013) conducted a research to examine the types of conflicts related with urban regeneration project and seek ways for preemptive prevention as well as expost resolution of conflicts, thereby proposing plans to facilitate implementation of urban regeneration projects. Conflicts in urban regeneration projects were caused by various issues related with implementation of urban regeneration, such as housing-centered residential regeneration, unilateral implementation method focused on removal, concentration around certain regions, civil sector-led project focused on profit making and alienation of residents from project implementation, and lack of understanding by the residents. As for plans to relieve conflicts in urban regeneration projects, the researchers proposed preventive conflict relief plans and expost conflict management plans. The preventive plans included governance-based project implementation through participation of various interested parties, securing public nature of the projects through participation of public institutions and doing away with unilateral method focused on removal, and adopting diverse ways to regenerate the urban areas. The expost conflict management plans represent ways to resolve mutual distrust and build mutual trust. First, plans to resolve conflicts with owners of land and buildings included adequate monetary compensation and provision of rights to move into the buildings to be built. And the plan to resolve conflicts with tenants is to adopt diverse compensation plans which the tenants can choose from.

Lee et al.(2009) laid down types of conflicts in urban regeneration projects in terms of various phases and parties, so that parties participating in urban regeneration projects may detect potential conflicts in advance and seek counter measures. The research covered 113 urban regeneration projects, and the researchers analyzed the conflict types in terms of various phases and parties. The analysis produced the following conflict types. 
Type A Conflicts (Planning Phase: Establishment of Master Plan/ Union-Administrative Office) are caused by disagreements over project implementation and methods, disagreements over participation of civil sector companies, requests for deregulation aimed at securing project feasibility, frequent policy changes and unclear criteria. Type B Conflicts (Implementation Phase 1:Union Establishment Implementation Committee/Union-Union) include distrust within the union and between union members, conflicts within the union related with selection of cooperating companies, conflicts over initiative in establishing the union, conflicts with other unions formed by parties seeking speculative investment. Type C Conflicts (Implementation Phase 1: Authorization for Union Establishment/ Union-Administrative Office) include conflicts caused by unclear criteria for administrative processes, conflicts over selection of construction companies. Type D Conflicts (Implementation Phase 1:Authorization of Management/Disposal Plan/Union- Administrative Office) include conflicts caused by unreasonable compensation and relocation plan for tenants, conflicts over unclear criteria for division of infrastructure expenses, conflicts caused by inefficient administrative procedures and approval criteria, and conflicts caused by lack of instructions or aid related with management/ disposal plans.

\subsection{Institutional Researches Related with Conflict Management}

Park(2011) reviewed the Regulations on Prevention and Resolution of Conflicts by Public Institutions, two draft conflict management laws submitted to the National Assembly and the draft conflict management law proposed by the Social Integration Committee, an advisor group for the President. Through this review, Park analyzed which direction the conflict management laws and systems are taking, identified relevant issues, and proposed the future direction for South Korea's insitutionalization of conflict management 1 ). The analysis revealed that the current institutionalized provisions on conflict management does not include provisions on applicability limit and conflict prevention. For future institutionalization of public conflict management in South Korea, Park proposed preparation of active conflict prevention plans and procedures for collecting opinions on government policies, reinforced inspection on current situation of conflicts involving the government, and reform of the Conflict Management Review Committee System.

$\mathrm{Ha}(2007)$ conducted a research to verify whether the conflict management efforts by the government produced the intended

1) Regulations on Prevention and Resolution of Public Conflicts was enacted in March 2013, and began enforcement this year. effects, so as to propose appropriate plans for conflict resolution in the public sector. The dependant variable is level of conflict resolution, and the independent variables are methods of administrative conflict management, provision of financial incentive and level of residents' participation. The control variables are conflict characteristics and conflict environment cluster. The cases subject to analysis were those where the government (central/local) caused tye conflict, those represented in extra-government press or reports, and those resolved during the period from 1995 to June $2006(n=213)$. The analysis showed that: 1) alternative conflict management method led to higher level of conflict resolution compared with conventional method; 2) higher level of residents' participation produced more positive effect on conflict resolution. It would be difficult, however, to achieve fundamental resolution of conflicts only with these two variable: plans should be established to create mutual synergic effect through provision of financial incentives and systems for participation of interested parties.

Hong and Kim(2007), under the recognition that public conflict management institutes do not offer effective resolution of conflicts in the public sector, conducted a research to identify issues with public conflict management institutes and propose ways to resolve the issues. They found that the problems with public conflict management institutes are low utilization rate and low effectiveness. In order to resolve various conflicts by revitalization public conflict management institutes, therefore, their utilization rates and effectiveness should be improved, for which the researchers proposed the following specific plans. Plans to improve the utilization rate included change of attitudes towards conflict management and management institutes, change of non-permanent institutes into permanent institutes, preparation of specific guidelines for institute administration, supplement of the preventive monitoring function and provision of authorities to public conflict management institutes and attracting the heads of public agencies to pay more attention to the issues. Plans to improve effectiveness included: field-oriented conflict resolution through improvement of conflict management capabilities on the field, active use of alternative dispute resolution (ADR) methods, readjustment of the roles of public conflict management institutes, flexible administration and use of the activities of the institutes as opportunities for policy learning

In response, the government enacted the Regulations on Conflict Prevention and Resolution of Public Agencies in 2007 for the purpose of preventing public conflicts, which it began to implement for central administrative institutions starting from May 2007, to institutionalize conflict management. This effort seems somewhat 
belated considering the fact that various countries including the United States and France are already managing public conflicts under various systems and laws related with public conflicts: however, this effort can be deemed positive in that it drew conflict management into South Korea's institutiaonl framework (Park et al., 2008). The Regulations provide that conflict impact assessment may be performed on projects with crucial and comprehensive influence on people's living or with possible risk of resulting in excessive social cost due to conflict of interest among people, before implementation of public policies, to prevent conflicts (Article 10) ${ }^{2}$. However, while the Regulations apply to central administrative agencies, the Regulations do not make it mandatory to the same system, only providing that local governments and public agencies may operate conflict management systems similar to that under the Regulations (Article 3).

Park(2011b) argued that, while proper execution of conflict impact assessment is imperative for effective prevention and resolution of public conflicts, pointed out that the consensus forming procedures proposed in the conflict impact assessment should be properly implemented during conflict arbitration, and proposed the following requirements for conflict management: fair and objective attitude of persons responsible for conflict assessment and arbitration, compliance with the information disclosure principles, ceaseless efforts to find alternatives to the issues, conversion from a single-issue structure to multiple-issue structure and recognition of the importance of the local politics aspects.

\section{Overview of Happiness Housing Project and Related Conflicts}

\subsection{Project Overview}

\subsubsection{Concept}

The concept of Happiness Housing Project changed somewhat while going through several phases: before conflict with residents (pledge from Park Geun Hye government during the Presidential Election), conflict elevation phase (at the time of announcement of the pilot sites) and post-conflict phase (after announcement of the Follow-up Action Plan) (Ministry of Land, Infrastructure and Transport, 2014).

The concept included in the election pledge was to "new type of combined residential town where apartments, dormitories and commercial facilities are built on artificial sites created on

Table 1. Previous Researches Related with Conflicts over Happiness Housing Project

\begin{tabular}{|c|c|c|c|}
\hline Area & Researcher & Purpose & Summary \\
\hline Rental housing & $\begin{array}{c}\text { Ha, Seong } \\
\text { Gyu et al. } \\
(2007)\end{array}$ & $\begin{array}{l}\text { Conflict management } \\
\text { plans for National } \\
\text { Rental Housing } \\
\text { Construction Project }\end{array}$ & $\begin{array}{l}\text { (Cause of Conflicts) } \circ \text { Failure to apply the result of environmental review due to forced } \\
\text { implementation, forcing rental housing of local governments, conflict with local urban planning } \\
\text { o Inefficient distribution of National rental housing sites caused by lack of consultation in the } \\
\text { public field due to unrealistic project schedule } \\
\text { Creation of slums and separation of residential areas due to housing supply focused on smaller } \\
\text { houses, caused by unrealistic construction cost }\end{array}$ \\
\hline \multirow{2}{*}{$\begin{array}{c}\text { Urban } \\
\text { Regeneration }\end{array}$} & $\begin{array}{c}\text { Park, Jeong } \\
\text { Woo et al. } \\
\text { (2013) }\end{array}$ & $\begin{array}{c}\text { Conflict relief plans } \\
\text { for urban regeneration } \\
\text { projects }\end{array}$ & $\begin{array}{l}\text { (Causes of Conflicts) housing-centered residential regeneration, unilateral implementation method } \\
\text { focused on removal, concentration around certain regions, civil sector-led project focused on } \\
\text { profit making and alienation of residents from project implementation, and lack of understanding } \\
\text { by the residents. }\end{array}$ \\
\hline & $\begin{array}{l}\text { Lee, Seul Gi } \\
\text { et al. (2009) }\end{array}$ & $\begin{array}{l}\text { Classification of } \\
\text { conflict types related } \\
\text { with urban } \\
\text { regeneration projects }\end{array}$ & $\begin{array}{l}\text { Proposed types of conflicts generated during urban regenration projects in terms of phases and } \\
\text { parties, so that parties participating in urban regeneration projects may detect potential conflicts } \\
\text { in advance and seek counter measures ( } 5 \text { types) }\end{array}$ \\
\hline \multirow{2}{*}{ Institution } & $\begin{array}{c}\text { Peak, Heung } \\
\text { Yeop } \\
\text { (2011a) }\end{array}$ & $\begin{array}{l}\text { Plans for } \\
\text { institutionalization of } \\
\text { conflict management }\end{array}$ & $\begin{array}{l}\text { o Preparation of active conflict prevention plans } \\
\text { o Preparation of procedures for collecting opinions on government policies } \\
\text { - Reinforced inspection on current situation of conflicts involving the government } \\
\text { - Reform of the Conflict Management Review Committee system }\end{array}$ \\
\hline & $\begin{array}{l}\text { Ha, Hye } \\
\text { Yeong } \\
(2007)\end{array}$ & $\begin{array}{l}\text { Effectiveness analysis } \\
\text { on the government's } \\
\text { conflict management } \\
\text { methods }\end{array}$ & $\begin{array}{l}\text { - Alternative conflict management method led to higher level of conflict resolution compared } \\
\text { with conventional method } \\
\text { o Higher level of residents' participation produced more positive effect on conflict resolution } \\
\text { o Financial incentive has moderate effect on conflict resolution }\end{array}$ \\
\hline
\end{tabular}

2) Article 10 provides " may conduct conflict impact analysis before making decisions on the relevant public policy." 
railroad sites.'

Around the time of announcing the pilot districts, the concept meant 'regions with specialized districts for environment, university, communication, sports and multi-culturalism, and nature-friendly combined residential towns designed to incorporate rental housing and office/commercial functions in conjunction with urban regeneration of the surrounding area, to attract social corporations to create more jobs. Recently, the concept seems to be going through further expansion as diverse methods are proposed for utilizing the housing sites in ways that conform to the home-work proximity and low rent conditions.

\subsubsection{Purpose and Targets}

The purpose of the Happiness Housing Project is to improve the living quality of the residents, revitalize the local economy, and preparing residential foundation for socially active classes within the urban areas, so as to help them find footholds for their independence through access to transportation and reduced residential cost. The Happiness Housing targets those having difficulties in securing their own houses due to instable or low income, such as people who just began their careers, newlyweds, aged citizens and university students.

Regarding the objective of local economy revitalization, the complexes will function as center for communication, exchange, job creation, culture and welfare not only for the people living in the rental houses but also residents of the surrounding areas.

\subsubsection{Project Description}

An annual project expense of 2.46 trillion KRW will be put into the Happiness Housing Project from 2013 to 2018, bringing the total project budget to $14,737.8$ billion KRW. The construction expense will be financed with 40-year loan from the National Housing Fund (grace period: 3 years, repayment period: 37 years). The total amount of rental houses and dormitories to be supplied is 200 thousand, and the rental apartment houses will be provided in two types: 13-pyeong type and 18-pyeong type, while the dormitories will be provided also in two types: 6-pyeong type and 9-pyeong type.

\subsubsection{The Status of Pilot Districts of Happiness Housing Project}

7 pilot districts have been finalized for the project as of 2014 (Oryu-dong District, Gajwa District, Gongneung-dong District, Gojan District, Mokdong District, Jamsil District, Songpa District), and a total of 10,050 houses are scheduled to be built on the total area of $489,000 \mathrm{~m}^{2}$ (see Table 2). Based on the outcome of these pilot projects, the Happiness Houses will expand into 50 locations including 6 metropolitan cities and other major urban areas suffering from worsening shortage of rental houses.

As these initial policies came to face opposition from the local residents, however, the Ministry of Land, Infrastructure and Transport changed the direction of the policy at the end of last year to use more diverse types of sites. The Ministry of Land, Infrastructure and Transport announced the ${ }^{\top}$ Follow-up Action Plans for Real Estate Policies of 1st April and 28th August $\lrcorner$ on December 3rd 2013, which included revitalization plan for the Happiness Housing policy. The plan stated that the amount of Happiness Housing to be supplied will be reduced from 200 thousand to 140 thousand, and the ratio of newlyweds, career starters, university students among residents was readjusted from $60 \%$ to $80 \%$, as they are in dire need for work-home proximity. Above all, the plan sought to facilitate Happiness Housing supply by using various housing sites appropriate for the purpose of Happiness Housing. In case of public lands, available lands are to be identified based on demand from local governments, etc., and the available sites will be developed mainly through mid-to-small projects.

Table 2. 7 Pilot Districts for Happiness Housing Project

\begin{tabular}{c|c|c|c|c}
\hline District Name & Location & Area & $\begin{array}{c}\text { Number of } \\
\text { Households }\end{array}$ & Remarks \\
\hline Oryu-dong District & Oryu-dong, Guro-gu, Seoul & $109,000 \mathrm{~m}^{2}$ & 1,500 & Area around the Oryudong Station \\
\hline Gajwa District & Namgajwa-dong, Seodaemun-gu, Seoul & $26,000 \mathrm{~m}^{2}$ & 650 & Area around the Gajwa Station \\
\hline Gongneung-dong District & Gongneung-dong, Nowon-gu, Seoul & $17,000 \mathrm{~m}^{2}$ & 200 & closed section of Gyeongchun Line \\
\hline Gojan District & Gojan, Danwon-gu, Ansan-si, Gyeonggi-do & $48,000 \mathrm{~m}^{2}$ & 1,500 & Area around the Gojan Station \\
\hline Mokdong District & Mok1-dong, Yangcheon-gu, Seoul & $105,000 \mathrm{~m}^{2}$ & 2,800 & Mokdong Retarding Basin \\
\hline Jamsil District & Jamsil-dong, Songpa-gu, Seoul & $74,000 \mathrm{~m}^{2}$ & 1,800 & Jamsil Retarding Basin \\
\hline Songpa District & Garak-dong, Songpa-gu, Seoul & $110,000 \mathrm{~m}^{2}$ & 1,600 & Tancheon Retarding Basin \\
\hline
\end{tabular}

* Source : Homepage of Ministry of Land, Infrastructure and Transport 
Table 3. Supply Plans for Each Type of Happiness Housing Site(tentative)

\begin{tabular}{|c|c|c|c|}
\hline \multicolumn{2}{|c|}{ Site Type } & $\begin{array}{c}\text { Amount } \\
\text { (tentative) }\end{array}$ & Description \\
\hline \multicolumn{2}{|c|}{ Public use } & 38 thousand & $\begin{array}{l}\text { Railroad sites, development sites around railroad stations, public parking areas near stations, } \\
\text { retarding basins, public facilities site, etc. }\end{array}$ \\
\hline \multicolumn{2}{|c|}{ Urban regeneration site } & 36 thousand & $\begin{array}{l}\text { Residential environment improvement site }(10,000) \text {, deteriorated residential sites }(16,000) \text {, } \\
\text { deteriorated rental housing complexes/ industrial complexes }(10,000) \text {, etc. }\end{array}$ \\
\hline \multirow{2}{*}{$\begin{array}{c}\text { Site owned by } \\
\text { public corporations }\end{array}$} & $\begin{array}{c}\text { Housing site for } \\
\text { public } \\
\text { construction }\end{array}$ & 39 thousand & $\begin{array}{l}\text { Coversion and utilization of lands around railroad stations and lands with work-home proximity } \\
\text { owned by public corporations( } \mathrm{LH}, \mathrm{SH} \text {, etc.) }\end{array}$ \\
\hline & $\begin{array}{l}\text { Site to be sold to } \\
\text { private entities }\end{array}$ & 27 thousand & $\begin{array}{l}\text { Coversion and utilization of lands around railroad stations and lands with work-home proximity } \\
\text { owned by public corporations }(\mathrm{LH}, \mathrm{SH} \text {, etc.) }\end{array}$ \\
\hline
\end{tabular}

* Source : Press release of Ministry of Land, Infrastructure and Transport (2013.12.3)

Urban regeneration will be implemented in conjunction with the existing residential environment improvement projects, whereby the Happiness Houses will be supplied separately or in combination with houses for sale in the private sector. In addition, houses and abandoned buildings in deteriorated residential sites including those released from new-town designation will be purchased and new houses will be built in those areas to be supplied as Happiness Houses. For career starters employed in industrial complexes, Happiness Houses with enhanced residential condition are scheduled to be built in urban high-tech industrial complex and mini combined towns $^{3)}$. Furthermore, some of the housing sites owned by $\mathrm{LH}$, $\mathrm{SH}$ or other public corporations will be selected for the project based on proximity to railroad stations and work-home proximity (see Table 3).

Supply amount will be allocated, and supply plan will be specified for each supply method and target areas, based on the results of demand survey from local governments. And supply methods suggested by each local government based on consideration of local circumstances will be adopted to diversify the project models.

\subsection{Conflict Overview and Development}

\subsubsection{Background}

In February 2013, the Presidential Transition Commission announced its plan to supply 200 thousand Happiness Houses for

3) Mini combined towns refer to small combined towns consisting of residential facilities including rental housing and other culture/ welfare facilities, constructed around industrial complexes for the purpose of improving residential environment for workers employed at the industrial complexes. There are twelve mini combined town projects currently under way across the nation(Ministry of Land, Infrastructure and Transport, 2013: 9). the next five years on railroad sites and unused national/public lands. In May 2013, the Ministry of Land, Infrastructure and Transport designated 7 pilot districts - Oryu, Gajwa, Gongneung, Mokdong, Jamsil, Songpa, Ansan and Gojan - and announced the plan to construct 10 thousand houses within the year.

\subsubsection{Surfacing of Conflicts}

Upon announcement from the government, starting from Yangcheon-gu Office and the Mokdong District, local residents in various districts including the Gongneung District organized countermeasure committees demanding cancellation of the construction plan, and the controversy spread as residents of the Jamsil/ Songpa District, Songpa-gu organized their own countermeasure committee and publicly opposed the plan. The specific grounds for opposition varied from district to district, but most of them referred to possible land price drop due to construction of rental housing complexes and loss of unused sites.

\subsubsection{Conflict Development}

In the course of these conflicts, in August, the Ministry of Land, Infrastructure and Transport designated only Oryu and Gajwa Districts as pilot districts on account of positive reponses from the areas. In particular, during the national inspection on the Ministry of Land, Infrastructure and Transportation conducted by the National Assembly Land \& Transportation Committee in October 2013, the Committee pointed out numerous problems including excessively high construction cost, possible increase of LH's debt, controversy regarding land use fee and preliminary feasibility survey. Other circumstances continuously fueled the controversy regarding the project's legitimacy and necessity, especially in the political sphere. 


\subsubsection{Current Status}

In December 2013, the government adjusted the planned amount of Happiness Housing Supply from 200 thousand to 140 thousand. The reason given by the government for such readjustment was that Happiness Housing Supply may result in reduced supply of national rental housing and other rental housing, effectively taking the opportunities for residential welfare away from low-income classes. The adjustment, however, seems to have been at least partially motivated by the government's analysis of the situation that there are only 2 districts realistically available for the project due to opposition from the local residents, etc.

As of January 2014, the government is taking various alleviative measures including alleviating restrictions on building-to-land ratio, floor area ratio and heights, and connecting the project with existing urban regeneration projects thus reducing the area of national/public lands used in the project by half. In addition, the government is making efforts to expand Happiness Housing
Projects to outside Seoul and the Seoul Metropolitan Area.

The Ministry of Land, Infrastructure and Transport has begun the groundwork for enforcing the revised 'Special Act on Public Housing Construction, etc.' and revising other implementation procedures, in order to ensure facile implementation of the Happiness Housing Projects. The revised Act is expected to include provisions on 'candidate sites review meeting' where local governments participate in the construction process, and 'candidate sites selection committee' where various parties including experts from the private sector may participate. According to the revised Act, designating and selecting Happiness Housing candidate sites should be preceded by publication of relevant information, consultation with local governments and experts, and holding review meetings with local governments, experts and constructors before proceeding with the relevant procedures such as proposal of housing site designation.

Table 4. Development of Conflicts Related with Happiness Housing Project

\begin{tabular}{|c|c|}
\hline Date & Description \\
\hline 2012.09. 23 & $\begin{array}{l}\text { Park Geun-hye, then a president candidate, announces the Happiness Housing plan as a part of the 'A World without Housing } \\
\text { Problem' for low-income / middle-class citizens. }\end{array}$ \\
\hline 2013. 02. 21 & 'Construction of 200 thousand Happiness Houses within 5 years' is included in the 140 Agendas \\
\hline 2013. 04.23 & $\begin{array}{l}\text { The Ministry of Land, Infrastructure and Transport finalizes the Housing Policy Implementation Plan by submitting it to the } \\
\text { Cabinet Meeting }\end{array}$ \\
\hline 2013.04.19 05.15 & Prior consultation with local governments of metropolitan regions, Korean Railroad Corporation, Korean Rail Network Authority \\
\hline 2013. 05. 20 & $\begin{array}{l}\text { The Ministry of Land, Infrastructure and Transport, Happiness Housing announces } 7 \text { pilot districts. Second announcement } \\
\text { mentioned inclusion of districts outside the Seoul Metropolitan Area }\end{array}$ \\
\hline 2013. 05. 27 & Happiness Housing SNS meeting for communication with the people \\
\hline 2013. 05. $\sim 06$ & Opposing residents organize countermeasure committees \\
\hline 2013. 06. 03 & $\begin{array}{l}\text { Yangcheon-gu Office publicly opposes the project, maintaining that the government selected and disclosed pilot districts without } \\
\text { prior consultation }\end{array}$ \\
\hline $2013.06 .05 \sim 07.05$ & Public display \\
\hline 2013. 06. 12 & $\begin{array}{l}\text { The Ministry of Land, Infrastructure and Transport holds the public hearing for Happiness Housing(Korea Research Institute for } \\
\text { Human Settlements). Local residents from } 5 \text { districts participated in the hearing, expression strong opposition }\end{array}$ \\
\hline 2013. 06. 13 & $\begin{array}{l}\text { The Ministry of Land, Infrastructure and Transport holds presentation for local residents at each district. Presentations at some } \\
\text { districts cancelled due to residents' protest (Gojan, etc.). Relevant organizations engaged in rallies and protesting visits (signature } \\
\text { campaigns, one-person rally, public hearing, etc.) }\end{array}$ \\
\hline 2013.07.02 03 & $\begin{array}{l}\text { - The Ministry of Land, Infrastructure and Transport holds additional presentation for Oryu-dong District residents } \\
\text { - Yangcheon-gu Assembly holds civil-government permanent council against Happiness Housing construction } \\
\text { - Yangcheon-gu Assembly forms a special committee against Happiness Housing }\end{array}$ \\
\hline 2013. 07. 31 & The result of national survey on Happiness Housing is announced \\
\hline 2013.07.09 08.07 & $\begin{array}{l}\text { The Ministry of Land, Infrastructure and Transport consults with the Ministry of Environment regarding the Strategic } \\
\text { Environmental Impact Assessment(for } 5 \text { districts). Gongneung and Gajwa Districts excluded due to their small sizes }\end{array}$ \\
\hline 2013. 08. 22 & $\begin{array}{l}\text { The Ministry of Land, Infrastructure and Transport designates Oryu and Gajwa Districts as pilot districts. Gongneung District } \\
\text { excluded from the final project districts. Local residents from some areas (Gojan District) visit the Ministry of Land, Infrastructure } \\
\text { and Transport to protest }\end{array}$ \\
\hline 2013. 09 & $\begin{array}{l}\text { Local residents' organize a rally against Happiness Housing in Songpa District. Mokdong District residents' committee against } \\
\text { Happiness Housing holds a public hearing }\end{array}$ \\
\hline
\end{tabular}


Table 4. Development of Conflicts Related with Happiness Housing Project (continued)

\begin{tabular}{c|l}
\hline Date & \multicolumn{1}{c}{ Description } \\
\hline 2013.10 & Land \& Housing Corporation(LH) holds a report session for the result of preliminary presentation on the technology bidding. \\
\hline 2013. 10.07 & $\begin{array}{l}\text { The Ministry of Land, Infrastructure and Transport withholds bidding announcement scheduled on August 10th. The Ministry } \\
\text { orders LH to rewrite designs and quotations }\end{array}$ \\
\hline
\end{tabular}

2013. 10. 14 At the report session for LH' technology bidding during the National Inspection, the construction cost at Oryu \& Gajwa Districts (estimated at 17 million $\mathrm{KRW}$ per $3.3 \mathrm{~m}^{2}$ ) is criticized for being 4 times the construction cost of private constructors

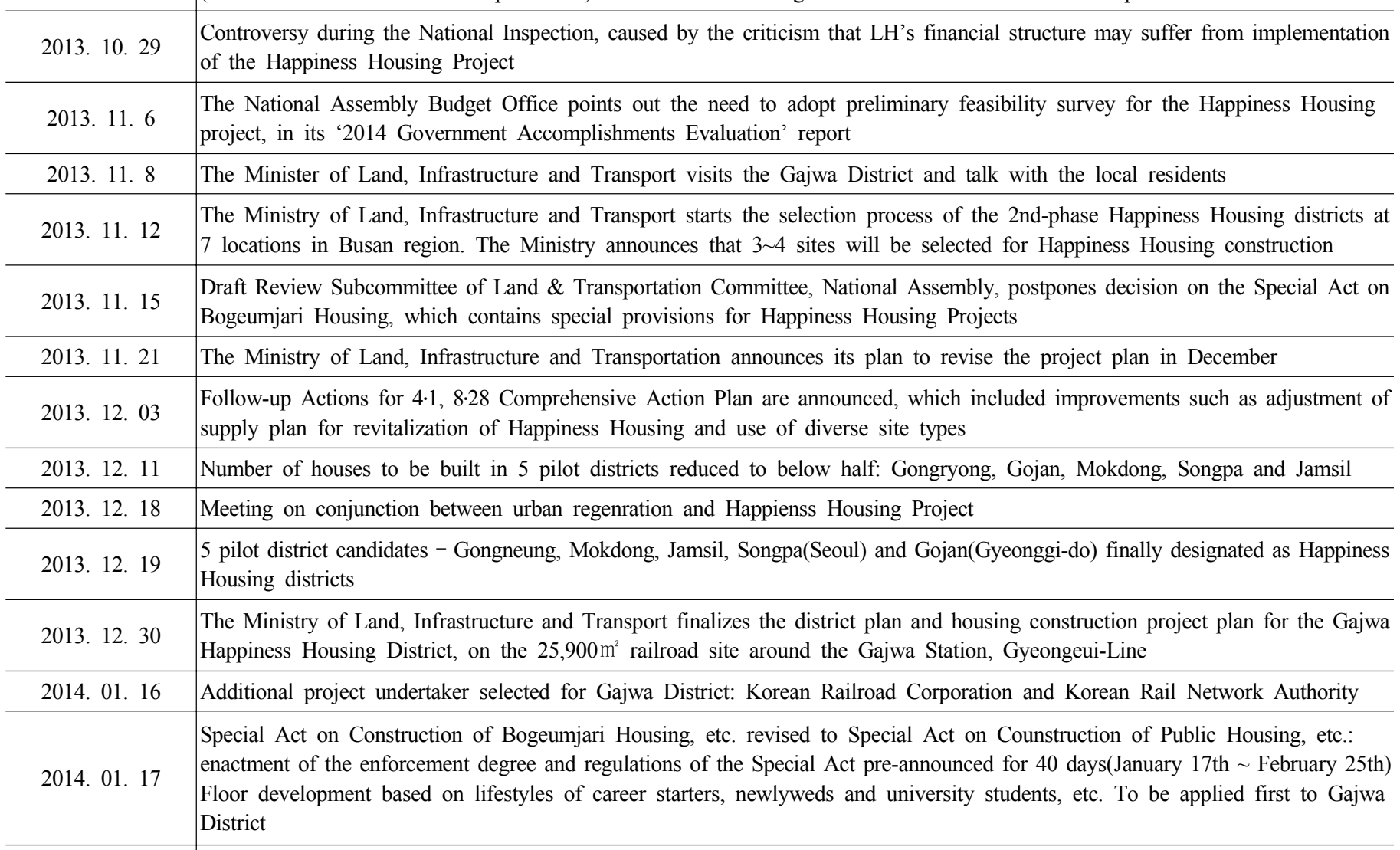
The Ministry of Land, Infrastructure and Transport announces its plan to adopt stricter verification process for Happiness Housing

2014. 01. 20 site candidates and mandatory consultation with local governments. According to this plan, the Ministry should improve Happiness Housing candidate sites designation and selection system, institutionalize consultation process with local residents, and determine the candidate sites after verification of their locational feasibility

Announced the plan to provide incentives in selection for urban regeneration projects, to local governments that implement

2014. 01. 22 Happiness Housing Project: additional points in selection for urban regeneration projects, discounted interests when borrowing construction funds, etc.

2014. 02. 05 2,560 to be constructed at two districts in Gwangju(Gwangju KTX Station, Seorimmaeul) and housing sites in Goyang, Samsong

2014. $02.12 \quad 2,450$ to be constructed at 4 districts in Incheon(Yeonsu Station, Juan Station, Dongincheon Station, Namgu urban residential area)

2014. 02. 14 Oryudong district plan and housing construction project plan approved: after construction begins, recruitment for residents will begin as early as late 2016

2014. 02. 24 Gajwa District to be developed as culture bridge with education, culture and leisure facilities that will improve the living quality of the residents

2014. 02. $27 \quad 2,120$ houses to be supplied at two places in Daegu(Daegu Innovation City, Daegu Techno Industrial Complex) and another 900 to Asan New Town

Joint Workshop of Happiness Housing experts: opinions gathered on selection criteria for Happiness Housing residents,

2014. 03. 26 convenience facilities for the residents and standards for construction, and the 1st Civil-Government Expert Council for Selection of Candidate Sites held(10 candidate sites selected) 


\section{Key Interested Parties and Issues Related with Conflicts}

\subsection{Key Interested Parties}

Key interested parties related with Happiness Housing can be classified into the following: the central government, public institutions implementing the project, local governments, local residents, political sphere and local NGO's (see Table 5).

The arguments of the each of the key interested parties can be summarized as follows. The Ministry of Land, Infrastructure and Transport and LH are project implementers, and thus supports the Happiness Housing Project. The Ministry of Environment, a central government department with high interest in the project along with the Ministry of Land, Infrastructure and Transport, aims to minimize the environmental impact from the project, and demands that the agreements included in the strategic environmental impact evaluation report be sufficiently reflected into the project.

The residents are divided into those for the project and those against. The residents supporting the project offer the various arguments: some demand securing of residential spaces, improvement of surrounding environments and ensuring of local development. In particular, beneficiaries from younger generations expect improvement of residential conditions through supply of low-rent rental houses at locations with easy access to transportation. In addition, Oryu District residents welcome Happiness Housing

Table 5. Key Interested Groups

\begin{tabular}{|c|c|}
\hline Parties & Key Groups \\
\hline $\begin{array}{c}\text { Central } \\
\text { government }\end{array}$ & $\begin{array}{l}\text { Ministry of Land, Infrastructure and Transport, Ministry } \\
\text { of Environment }\end{array}$ \\
\hline $\begin{array}{c}\text { Public } \\
\text { organization }\end{array}$ & LH, Korail, Korea Rail Network Authority \\
\hline $\begin{array}{c}\text { Local } \\
\text { governments }\end{array}$ & $\begin{array}{l}\text { Songpa-gu, Yangcheon-gu, Nowon-gu, Guro-gu, } \\
\text { Seodaemun-gu, Ansan-so }\end{array}$ \\
\hline Local residents & $\begin{array}{l}\text {-Proponents: some residents of Oryu \& Gajwa Districts, } \\
\text { beneficiaries of the project } \\
\text {-Opponents: local residents of Mokdong, Gongneung, } \\
\text { Gojan, Jamsil \& Songpa Districts } \\
\text { - Mokdong Resident's Emergency Committee Against } \\
\text { Happiness Housing Construction } \\
\text { - Gojan District Countermeasure Committee against } \\
\text { Happiness Housing Construction } \\
\text { - Gongneung District Countermeasure Committee } \\
\text { against Happiness Housing Construction } \\
\text { - Tancheon Retarding Basin Countermeasure } \\
\text { Committee against Happiness Housing Construction }\end{array}$ \\
\hline Political sphere & $\begin{array}{l}\text { National Assembly members, members of local } \\
\text { assemblies }\end{array}$ \\
\hline Local NGO & Environment groups, etc. \\
\hline
\end{tabular}

construction for the purpose of local development, which involves improving the region's image as an underdeveloped urban area and having facilities required by the local residents, and Gajwa District residents support the project in expectation of improvement of the surrounding areas and local development through conjunction with the park expansion projects.

Residents against project also offered a variety of arguments. Residents in Mokdong were concerned about deterioration of educational environment and quality, safety issues from the loss of retarding basins, worse traffic problem and insufficient number of schools compared with the population ${ }^{4}$ ). Residents in Ansan and Gojan are concerned about destruction of residential environment for the New Towns, weakening of the drive for national rental housing construction at Shingil Hot Spring, possible educational issues if the plan does not include founding new schools and insufficient infrastructure, inconveniences for local residents (the current construction site is being used as a public parking space). In addition, they point out the risk of introduction of new commercial facilities negatively affecting the existing businesses, rent decrease in the surrounding housing areas, damage to local sceneries due to construction of new houses, and deterioration of resiential environment caused by railroad noise and vibration.

Residents in Gongryong District express concern that the current site is where a park had been planned upon request from the local residents, and construction of Happiness Houses might lead to insufficient infrastructure, and the number of rental houses in the district is highest among Seoul's 25 autonomous Gu's, and construction of Happiness Houses will accelerate this trend.

\subsection{Key Issues}

The arguments above from key interested parties can be summarized as follows.

\subsubsection{Method of Project Implementation}

Some argue that the Ministry of Land, Infrastructure and Transport is imposing its decision upon local residents and governments, forcing them to accept decisions made by experts without any consultation with local residents or governments.

\subsubsection{Impact on the Surrounding Housing Market}

Although the Ministry of Land, Infrastructure and Transport

4) Yangcheon-gu is the region with lowest ratio of number of schools against population in South Korea. 
planned to supply public houses to career starters, newlyweds and other socially disadvantaged classes at lower prices $(50 \%$ of the market prices at first, later raised to $50 \sim 80 \%$ of the market prices), the interested parties interpreted it as signifying decrease of the rental housing market and the housing prices, which gave cause to worries about rent collapse.

\subsubsection{Impact on Living Quality}

Some express concern that construction of Happiness Housing will bring about negative impacts such as traffic congestion, overpopulation, noise/vibration, reduction of culture/convenience facilities, deterioration of urban areas, foreigners influx and reduced stability around rainy areas.

\subsubsection{Impact on Educational Environment}

Regions with higher ratio of school parents are against the project mainly on account of the expected negative impact of population influx caused by Happiness Housing construction on the educational environment of the region. Specifically, the opponents are concerned about deterioration of educational quality due to overcrowded classrooms, deteriorated academic aptitude, damage to the existing school districts and increased crime rate.

\subsubsection{Conflict with Existing Plans}

Some local governments are against the project arguing the Happiness Housing policy overlaps with some of the preceding policies already in progress, or it conflicts with project plans at the local government level in terms of location.

\subsubsection{Construction Cost}

Some National Assembly members maintain the project lacks feasibility estimating the construction cost of pilot districts in Gajwa and Oryu at 16.70 17.00 million KRW per $3.3 \mathrm{~m}^{2}$. On the other hand, the Ministry of Land, Infrastructure and Transport aruges that the construction cost varies depending on how the structures (decks, etc.) are designed, and expects that a small adjustment will be enough to make it possible to supply houses at lower prices than apartments in the Seoul Metropolitan Areas constructed by private companies.

\subsubsection{Insolvency of Public Corporations}

Some National Assembly members and NGO's have projected that the debt situation of some public organizations including $\mathrm{LH}$ will worsen due to implementation of the Happiness Housing project. They maintain that LH, which already carries debt of over 100 trillion KRW, will suffer from even more financial burden as the organization provides the construction expense for the Happiness Housing Project, and the project itself is not economically feasible as LH is expected to even shoulder the Happiness Housing rents of 8 billion KRW.

\subsubsection{Land Use Fee Issue with Korail}

Although the government stated there will be 'no pressure from the land price', Korail maintains that the corporation needs to impose a certain amount of land use fee for Happiness Houses constructed on unused railroad sites, and expects the rate of such use fee to be at least $2.5 \%$ of the evaluated value (appraised land value). Furthermore, in case the usage of land changes from railroad to quasi-residential site, the appraised value of the land is expected to double or triple, which will increase the amount of land use fee to be paid by LH and in turn increase the amount to be paid by each household to as much as 6 million KRW per year (480 thousand per month).

The Ministry of Land, Infrastructure and Transport and LH are of the opinion that the land use fee for free or considerably reduce the use fee.

\subsubsection{Need of Preliminary Feasibility Survey}

The National Assembly Budget Office evaluated the nation's major budget projects through its ' 2014 Government Accomplishment Evaluation' report. The report points out the need for preliminary feasibility survey on the Happiness Housing Project, arguing that the it should be carefully reviewed whether to continue with the project. The Ministry of Land, Infrastructure and Transport countered that it is not appropriate to apply the benefit/cost standard here, to a project implemented to further the government's goals related with residential welfare.

\subsubsection{Supply Amount and Additional Designation}

The amount of housing that can be supplied using national/ public lands in urban areas is 35,000, which accounts for only $18 \%$ of the target supply amount $(200,000)$. Some argue that it would be difficult to achieve the target supply amount even if the unused public facility sites currently being considered are actually used as housing sites. The Ministry of Land, Infrastructure and Transport plans to expand the supply amount by making new applications for areas outside the Seoul Metropolitan Area. 


\subsubsection{Timely Completion of Housing Construction}

Some expect that it will be impossible to complete the construction in time, arguing that many of the construction companies will have difficulties in participating in the bidding process for the Happiness Housing Project due to bid rigging and selection of unqualified bidder, etc.

\subsubsection{Actual Source of Demand}

With the mainstay of Happiness Houses expected to consist of smaller houses under $60 \mathrm{~m}^{2}$, the controversy continues that the Happiness Houses mainly target 1 2-member households such as university students, career starters and newlyweds, and it will be meaningless for the actual source of demand, the 3 4-member households.

\section{Analysis on Causes of Conflicts}

Review of the conflict development process and opinions of key interested parties revealed the following causes of conflicts.

\subsection{Under-deliberated Election Pledges}

The primary cause of conflicts is insufficiently developed election pledges only designed to attract votes. As was the case with Buan Radioactive Disposal Site project, Saemangeum Construction project and Sapyesan Tunnel Project, the primary source of conflicts related with the Happiness Housing Project was election pledges developed without sufficient deliberation.

Housing construction plans using public lands such as railroad sites have been repeatedly proposed under previous regimes, and most of them were abandoned due to issues with economic feasibility and reception by the local residents. Despite this history, the election pledges were established without appropriate measuers to prevent the past failures.

\subsection{Lack of Viability Review on Pledges}

The second cause of conflicts is the Ministry of Land, Infrastructure and Transportation, which blindly took over the plan. Even though the project was based on pledges made during the Presidential Election, it should have been designed based on realistic scope, level and procedures while considering its viability, feasibility and reception by the local residents.

\subsection{Lack of Conflict Management Plans}

Considering the history of past housing site development projects that spawned so much conflict, the current project should be been made based on careful analysis on the likelihood of conflicts and preparation of countermeasures to reduce resulting conflicts. The Presidential Decree on Conflict Prevention and Resolution states that, projects with high risk of causing conflicts with significant social impact should be subject to $\Gamma^{\circ}$ conflict impact assessment $\lrcorner$, and reviewed by a $\ulcorner$ Conflict Management Review Committee $\lrcorner$, and the Ministry of Land, Infrastructure and Transportation has its own regulations regarding such review process. The mechanism, however, did not work during the policy making phase of the current Happiness Housing project. This seems to be due to inexperience with applying the established institutional framework.

\subsection{One-way Implementation}

Conflict is inevitable in projects implemented without consent of actual interested parties. 7 pilot districts were selected with insufficient consultation with and opinion gathering from actual interested parties, local residents and governments, with the central government making decisions on its own through internal survey and imposing them on other parties.

\subsection{Project Plans Established without Sufficient Regard Local Circumstances}

Local contexts and characteristics were not adequately considered during the pilot sites selection process. It was the natural consequence of insufficient participation from key interested parties and lack of opinion-gathering. As establishment of the project plan was led by development plan experts, demands from local residents were not sufficiently reflected into the plan, which in turn caused conflicts in later stages.

\subsection{Frequent Project Revision}

Although suspicion about the project's feasibility spread from local residents to the political sphere, each problem was dealt with individual revision introduced after the problem was raised, rather than with an integrative plan based on overall reconsideration of the project implementation. This encroached on the project's reliability, and more suspicion was raised about the inconsistency of the government's policies.

\subsection{Underwehlming Level of Conflict Management}

Faced with worsening opposition from local residents and governments, the Ministry of Land, Infrastructure and Transportation have been making various efforts to explain the necessity of the Happiness Housing Project to local residents and persuade them 
to accept the project. While the local residents and governments raised specific and down-to-earth issues such as housing price collapse, deterioration of educational quality and traffic congestion, the government has been trying to promote and explain the central government's policies rather than creating a space for open and comprehensive discussion.

\section{Conclusions: Suggestions for Conflict Resolution}

Districts subject to the Happiness Housing Project experienced conflicts among their residents at the intial stage of the project implementation. Currently, the Project is continuing its implementation after settling the conflicts through diversifying the project types and site types. Possible causes for conflict, however, still remain in pilot sites except for Oryu and Gajwa districts. Therefore, in order to achieve sustainable implementation of the Happiness Housing Project and successful implementation of the project in pilot districts in the future, we need to make the following efforts.

\subsection{Viable Election Pledges}

Most public conflicts are caused by election pledges that are only designed to appease the public often leads to conflicts. Political candidates will and should provide pledges to win the voters' minds, but those pledges need to be reviewed in advance for possible economic issues they may cause and their acceptability by the relevant residents

\subsection{Thorough Verification of Pledges by the Relevant Departments}

Even pledges need to be subject to thorough verification by the relevant departments to assess its viability. Although they represent the candidate's commitment with the public, the relevant departments need to verify the viability of specific pledges so as to minimize possible negative impact from the project and maximize its effect. In addition, a lot of pledges are motivated by the need to win votes of certain classes or areas. When those pledges are made into actual polices, those policies are highly likely to cause conflicts due to issues related with fairness.

The relevant departments, therefore, should identify possible negative impacts of the relevant project in advance, and establish countermeasures to close the gap between its cost and benefit before it is implemented. Likelihood of conflicts need to be assessed in advance through such methods as conflict impact assessment.

\subsection{Gradual Implementation Based on Consideration of the Actual Circumstances}

Force-implementing a project to achieve its objectives is no longer a viable option. One of the reasons the conflicts about the Happiness Housing policy had so much social impact was that the Ministry of Land, Infrastructure and Transportation announced 7 pilot districts for a project with high risk of conflict, and the conflicts did occur in 5 of the designated districts almost simultaneously. As the project was met with starkly different reactions from each district, the pace of implementation should have been flexibly adjusted to the actual progress of the situation, implementing the project first in districts where positive reception was expected.

\subsection{Participation of Key Interested Parties}

It is imperative to gather opinions from the key interested parties. The primary cause of conflicts about the Happiness Housing Project is that the opinions of the interested parties were not sufficiently heard and gathered during selection of the pilot districts. No matter how noble the government's intentions are, the actual impact of a project may manifest in various ways. Unlike the past, people will express their dissent if a project benefits the majority but causes loss to themselves or their group. Therefore, before implementation of a project, the degree of 'discrepancy between cost and benefit' should be identified, and measures should be established to close the gap between the two. Accusing the dissenters of NIMBY attitude will not solve the problem.

\subsection{Consistent Policy}

Impromptu policy revisions only damage the reliability of government policies. The conflicts in this case were prolonged and transformed into political issues because the issues raised were dealt with impromptu responses rather than comprehensive, institutional solution based on foundational deliberation. These type of responses only damage the government's credibility and give cause to unnecessary misunderstandings.

In this regard, it is fortunate, although somewhat belated, that the government decided to improve the implementation method and procedures by reorganizing the relevant laws and regulations starting from December 2013.

\subsection{Conflict Management Techniques that Reflect the Reality}

Conflict managements relying on promotion, explanation and persuasion offer only limited results. In a situation complicated 
by complex network of interests, the Ministry of Land, Infrastructure and Transport sought to further its own objectives through promotion, explanation and persuasion rather than seeking a measure to reconcile the qualitative differences of interests. Such approach, however, will not be accepted by the public any longer. The interests of local residents should have been identified in a more precise manner, plans should have been established to remove unfairness, and a fundamental revision of the implementation process should have been introduced to solve the relevant procedural issues. In addition, in order to balance the interests within the group, a space for reasonable discussion should have been secured to grant opportunities for participation and measures should have been established that could satisfy more parties.

\section{References}

1. Choi, Byung Hak and Tae Soon Park (2009), An Analysis of Conflict Types related with the Geumgang Regeneration Project and Management Methods, Chungnam Development Research Institute.

2. Ha, Hye Yeong (2007), "Analysis on Factors Affecting Resolution of Public Conflicts: focused on effects of the conflict management factor", Korea Public Administration Review, 41(3): 273 296.

3. Ha, Seong Gyu and Seong Yeon Kim (2007), "Types and Management Methods of Conflict in Public Sector in National Rental Housing Construction Project", Korea Local Development Review, 19(3): 107 130.

4. Hong, Seong Man and Gwang Gu Kim (2007), “An Exploratory Study on Operation of Public Conflict Institutes and Their Effectiveness: focused on conflict management institutes for government conflicts", Korea Public Management Review, 22(4): 1 17.

5. Korea Institute for Women's Development (2005), Conflict Impact Assessment and its Political Implications.

6. Lee, Mi Hong et al. (2006), A Study on Environmental Governance Modelling, Land \& Housing Institute, Korea Land Corporation.

7. Lee Seul Gi, Hae Rim Gweon and Jeong Ho Yu (2009), “Analysis on Conflict Types in Urban Regeneration Projects", Korea Construction Management Review, 10(6): 78 87.
8. Ministry of Land, Infrastructure and Transport (2013), Follow-up Action Plans for Real Estate Policies of 1st April and 28th August.

9. Ministry of Land, Infrastructure and Transport (2014), A Study on Sustainable Supply of Happiness Housing.

10. Park, Heung Yeop and Jin Park (2008), "Conflict Impact Assessment Modeling and Exploration on its Applicability: focused on the New Nuclear Powerplant Construction Case in Uljin", Korea Personnel Administration Review, 7(3): 193 220.

11. Park, Heung Yeop (2011a), "Institutionaliztion of Conflict Management in the Public Sector", Korea Public Management Review, 25(1): 105 132.

12. Park, Heung Yeop (2011b), "SOC-related Conflict Impact Assessment and Arbitration", Spring Conference, Korea Association of Public Administration.

13. Park, Jeong Woo and Tae Su Song (2013), "Plans for Conflict Relief in Urban Regeneration Projects". Korea Policy Review, 13(3): 133 148.

14. Park, Tae Soon (2008), Environmental Conflict Issues in Jeollabuk-do and Countermeasures, Jeonbuk Development Research Institute.

15. Park, Tae Soon (2008), "Current Conflicts in Local Governments and the Basic Direction for Resolution : with focus on public officer's rule of behavior under conflicts", The 1st Policy Focus, Chungnam Development Research Institute.

16. Park, Tae Soon (2010a), Guidebook of Conflict Resolution: Conflict is the Eneregy for Co-existence, Happy Story.

17. Park, Tae Soon (2010b), White Paper of Residents' Movement regardign Buan Radioactive Waste Disposal Plant, Social Conflict Research Institute.

18. Presidential Advisors' Sustainable Development Committee (2005), Theories and Practice of Public Conflict Management (Volume 1), Nonhyeong.

19. Presidential Advisors' Sustainable Development Committee (2005), Theories and Practice of Public Conflict Management (Volume 2), Nonhyeong.

20. Yoon, Jeong Joong et al. (2013), "Significance of Happiness Housing, Overseas Cases and their Implications", Urban Information, 376.

21. Ministry of Land, Infrastructure and Transport homepage: http:// www.molit.go.kr

22. National Assembly Library homepage: http://www.nanet.go.kr

23. Happiness Housing homepage: www.molit.go.kr/happyhouse 